\title{
The Gothic genre, classical allusion and other influences in Oscar Wilde's The Picture of Dorian Gray
}

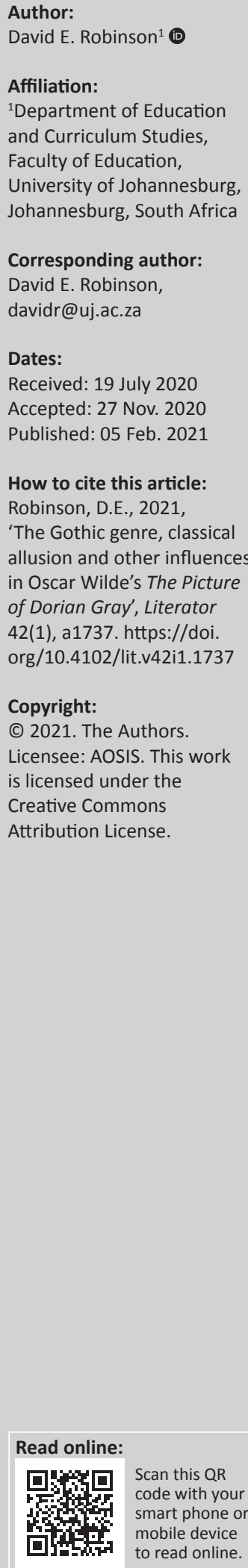

This article will outline the aspects of influence and allusion in the novel, with reference to Victorian Gothic, classical mythology, the psychological double, monster theory, the Faustian bargain, the mask and a prominent memento mori in Huysmans' A Rebours, his description of Rodolphe Bresdin's lithograph, 'The Comedy of Death'. Wilde's novel is a complex, multilayered text, and a richer, more profound understanding of it becomes possible when it is situated within this context of influence and allusion.

Keywords: The Picture of Dorian Gray; Oscar Wilde; the Gothic genre; the Victorian age; classical allusion; Freud; the double; monster theory; Joris-Karl Huysmans; Rodolphe Bresdin.

\section{Introduction}

Oscar Wilde's only novel, The Picture of Dorian Gray, a Victorian-era novel in the Gothic genre, is one of the two possible texts selected for study in Grade 12 Home Language English in South African government/state schools (Department of Basic Education [DBE] 2016:2, 2018:4). At one level, The Picture of Dorian Gray is a simple narrative - a man who is the subject of a painting wishes to remain young and unmarred, while his portrait reflects the consequences of ageing and debauched living. The wish is mysteriously granted, and Dorian Gray remains youthfully attractive, while the image in the picture (concealed in an upstairs room) grows increasingly old and sinister, in concert with the character's evil doings. The story moves through a tragic arc and ends with Dorian's unintended self-inflicted death, at which point the mysterious doubling process is reversed: his dead body is seen to be that of an old man, and his image in the picture is restored to its former youthful state (Wilde 2003:213).

Approached in terms of this bare narrative, the novel can indeed be appreciated, but in a somewhat superficial way. Missing from this paraphrase is an awareness of the vital role the Gothic aspects and various other influences and connections in the text play, which make reading it a richer and far more rewarding experience than an uninformed reading can allow.

\section{Early influences}

Early influences on Wilde's writing include stories from his parents, who were themselves influenced by Irish folklore (Fitzsimons 2015:32). Wilde's mother, Jane Francesca Wilde (writing under the penname 'Speranza' - Italian for 'Hope'), translated a story entitled Sidonia the Sorceress, a German romance (1884) by Wilhelm Meinhold (Gardiner 1995:12), which was a favourite of Wilde's childhood (Sturgis 2018:33). Ellmann (1987:19) points out that the tale of Sidonia also 'fascinated the Pre-Raphaelites; Burne-Jones did a painting of her'. In a description of this painting by William Morris, two images of Sidonia are present: 'in the foreground....is a woman golden-haired and richly gowned, while in the background lurks the ravening sorceress' (Ellmann 1987:20). The idea of a painting presenting an altered doubling of its subject has clear echoes in Wilde's novel.

Another work by a family member which inspired young Oscar was the Gothic novel Melmoth the Wanderer, which was written by Charles Robert Maturin, his great uncle (Ellmann 1987:6). In this novel, there is both a concealed painting and a character unchanged by the passage of time (Maturin 1977:60-65). Wilde, then, would have been familiar with these Dorian Gray-type motifs from an early age (Wilde 2003:117). A minor point relating to Maturin's novel is that, after Wilde's release from prison (following the Marquess of Queensbury scandal) (Ellmann 1987:495), he adopted the pseudonym Sebastian Melmoth, an obvious reference to the fictional creation of his great uncle, as well as to the name of his favourite martyr (a fact which might be seen as a late classical allusion) (Ryder 2013:9). 
Regarding Wilde's relation to the classics, it should be appreciated that he excelled in both Greek and Latin at Oxford (Wright 2008:83-84). His knowledge of classical languages and culture was considerable. Thomas Wright makes the point that there was a social purpose to Wilde's demonstration of such knowledge; it was this knowledge that differentiated the educated classes from the lower classes in British society, and so (such were the prejudices of the time) helped distance Wilde from his provincial Irish roots. 'My Irish accent was one of the many things I forgot at Oxford' is one of his sayings which encapsulates his awareness of the social disadvantages of his origins (in Ellmann 1987:37).

If Wilde wished to be acknowledged for his superior intellect (Wright 2008:83), he also wished to be acknowledged for his refined aesthetic sensibility and was aided in this pursuit by one of the celebrated academics at Oxford, Walter Pater (Ellmann 1987:46). Wilde read Pater's The Renaissance in his first term at Oxford (Wilde 2015:37). In it, Pater (Pater \& Wilde 2003) makes the following point about art and its appreciation:

What we have to do is to be for ever curiously testing new opinions and courting new impressions, never acquiescing in a facile orthodoxy of Comte, or of Hegel, or of our own. Philosophical theories or ideas, as points of view, instruments of criticism, may help us to gather up what might otherwise pass unregarded by us. (p. 30)

Pater urges the 'testing [of] new opinions' and 'courting [of] new impressions', in order to challenge dull orthodoxy and complacency. The implication here is that the purpose of art is to provide an audience with new opinions and impressions through which to develop a heightened appreciation of both art and life. In his comment on art at the beginning of Dorian Gray, Wilde (2003:4) states: 'All art is quite useless'. Is this contrary to Pater's sense of the intellectually and emotionally enlivening purpose of art? No. Wilde's deliberately provocative statement actually critiques the idea that the value of something is based on practical usefulness and implies that the value of art is to be sought elsewhere, not in the practical world, but equally not in the world of complacent aesthetic indulgence, a lesson meted out by his example of the vapid Lord Henry Wotton in the novel.

It is possible to see Dorian Gray as a Paterian figure, because of his transgressional wish to prolong his own youth and beauty, which, apart from its nod to Paterian aestheticism, can be read as a challenge to social orthodoxy, if of a rather self-absorbed kind. Christopher Nassaar, however, believes that, following his reading of the yellow-backed French novel offered to him by Henry Wotton (to be more fully discussed in the penultimate section of this article), Dorian Gray experiences an intensification of Pater's position (Wilde 2003:162): he goes 'beyond anything the race - including... the modern Paterian man - has yet known, and will become the visible symbol of [Lord Henry] Wotton's new hedonism' (Nassaar 1985:120). The consequence of embracing this hedonistic position is for Dorian to 'seek beauty in evil... and [thus] become a full-blown decadent' (Nassaar 1985:120).

\section{The Gothic genre}

It is notable that Maturin's work falls into the Gothic genre, as already indicated. Wilde's novel can also be located within this genre. Interestingly, apart from Maturin's Melmoth, certain other Gothic works contain examples of supernaturally endowed paintings, as discussed in Robert Mighall's introduction to Dorian Gray. In Horace Walpole's The Castle of Otranto (1794), a figure steps out of a painting. In 1812, Jean Eyries published a collection of stories, Fantasmagoriana, containing 'Family Portraits', in which a painting of an evil man is created by a ghost. During his life, the painting mirrors the subject's evil nature, but after he dies it reverts to its initial appearance. Another example of an uncanny painting is found in Edgar Allan Poe's The Oval Portrait (1845) (Mighall 2000:xviii), in which a narrator, strangely disturbed by the lifelikeness of the portrait of a beautiful young woman, reads that she died, unobserved, while sitting day after day for her relentless artist husband. These examples are an indication of the firm presence of this type of supernaturally themed painting in Gothic literature. The works were all well known and were very likely read by Wilde; he was certainly familiar with the writings of Poe (Ellmann 1987:148).

M.H. Abrams and Geoffrey Harpham point out that the word 'Gothic', as it pertains to literature, has evolved over time (Abrams \& Harpham 2012:152), an opinion echoed by Mulvey-Roberts (ed. 1998:xv). Originally, Gothic novels tended to deploy medieval settings, with their suggestive castles and abbeys. Victorian Gothic settings - as manifested in the London of Dorian Gray - tended to lack these historical trappings, but developed 'a brooding atmosphere of gloom and terror'. Supernatural and macabre events, along with depictions of psychological 'aberration', were common to the genre (Abrams \& Harpham 2012:152). Such aberration can probably be ascribed to Dorian Gray, in that he is aware of the duplicitous nature of his presentation of himself; his public persona differs from the reality captured in the hidden portrait. In Chapter 16, Dorian engages a hansom cab to take him to an opium den; his use of opium, a mindaltering substance, might be seen as an indication of psychological aberration - he is deliberately choosing to embrace the world of behavioural and psychological deviance (Wilde 2003:176).

In commenting on the concept of the Gothic, Dani Cavallaro (2002) states that:

This term is here employed to refer to a cultural discourse that utilizes images of disorder, obsession, psychological disarray and physical distortion for the purposes of both entertainment and ideological speculation. (p. vii)

This statement presents two elements for consideration: 'entertainment', which points to the popular appeal of the genre (and a possible element of superficiality); and 'ideological speculation', which suggests that there is a deeper aspect to the genre that lends itself to significant critical engagement, in which fundamental questions about 
humanity might be explored. Like Abrams and Harpham, Cavallaro notes the presence of psychological disorder and also includes physiological distortion, suggesting in all this that the genre broaches topics and approaches that challenge conventional or comfortable world views. Fred Botting (2005:3) offers a useful summary regarding such challenges: 'Gothic excesses transgressed the proper limits of aesthetic as well as social order in the overflow of emotions that undermined boundaries of life and fiction, fantasy and reality'.

\section{The 'double' and dualities}

The idea of the 'double', found in many Gothic texts, is addressed by Sigmund Freud, as Andrew Smith observes (Smith 2013:6). The projection of the double is, for Freud (2003:142), an 'insurance against the extinction of the self or, as Rank puts it "an energetic denial of the power of death"'. Although Freud credits Otto Rank's insight, Antonio Ballesteros Gonzalez states that the 'double' was a term originally coined by the German writer Jean Paul and that it ultimately came from 'the anthropological belief in an innate duality in man', based on ancient archetypes of 'Otherness' (in ed. Mulvey-Roberts 1998:264). Such archetypes, though, are not unallied to more recent psychological thought regarding the subconscious, such as those of Freud (to say nothing of Jung). There is an undeniably strong similarity between Freud's theory and Wilde's narrative, in that his portrait provides Dorian with a type of 'denial of the power of death'. Another important element to consider is the loss of a committed self in the presence of a double and an ensuing temptation to flout social responsibility by blaming the double for all transgressions (Freud 2003:142). Wilde's novel, indeed, presents us with a protagonist who engages in various immoral acts, including the murder of the artist Basil Hallward, while taking no responsibility for these acts, and projecting them metaphorically, through their grotesque 'physiological distortions', on his 'double', the portrait.

Dualities of existence extend into environments, as well as social spaces. Tamara Wagner (2014), in Gothic and the Victorian Home, presents the Victorian home as a haven, in which the difficulties of the world (imaged, metaphorically again, through Gothic elements) can be fended off:

In Victorian Britain the Gothic lent itself as a means of exploring new challenges and threats: to articulate anxieties about modernity - new technologies, the results of rampant industrialization - and to new awareness of mental illness, crime and the anonymity of expanding urban spaces. (p. 110)

This duality is constructed from a sense of anxiety concerning the points of difference between the old and the new, and the associated concerns with having to relinquish the old (or established) for that which is new, unknown and possibly threatening. Wagner quotes Peter Ackroyd's comment about 'fireside cosiness' in Dickens's Christmas stories: 'and do we not enjoy the flames of the Christmas fire more because of the very shadows which it casts?' (in Wagner 2014:110). There are two types of enjoyment conveyed by this comment - one linked to the light and warmth of the fireside and the other to the thrill of the darkness (real and metaphorical). In Dorian Gray, comfortable Victorian social life (indulged in by well-off males) is juxtaposed with the depravities of the protagonist, showing Wilde's keen awareness of this duality. For example, when Lord Henry goes to his aunt for a meal, notably present are duchesses, knights, and lords and ladies (Wilde 2003:38). By contrast, beyond the fireside cosiness of Lord Henry's privileged world, there is the shadow of Dorian's double life. A notable example is presented in Chapter 16, where (as already mentioned) Dorian travels by hansom cab into the anonymity of expanding urban spaces', to find an opium den (Wilde 2003:176). Wilde's description presents a grotesquely threatening world: 'The moon hung low in the sky like a yellow skull' (Wilde 2003:176). There is in this image a suggestion of impending doom, linked to addiction and transgressive behaviour. Significantly, Dorian is of both light and dark worlds; he is the living embodiment and symbol of the dualism of the light and shadow elements of existence.

\section{Thematic connections to other Gothic texts}

An awareness of other works of Victorian Gothic helps develop a deeper appreciation of The Portrait of Dorian Gray. Consider Robert Louis Stevenson's The Strange Case of Dr Jekyll and Mr Hyde (Stevenson 2002), or Bram Stoker's Dracula (Stoker 1993). Matthew Sturgis emphasises the connection between Wilde's novel and that of Stevenson (Sturgis 2018:515). Dr Jekyll has a monstrous alter ego, a type of 'double', in Mr Hyde (Stevenson 2002:57). Mighall notes that 'Edward Hyde is the embodiment of what Jekyll refers to as his "lower elements" ... Hyde is imaginary and potential until Jekyll discovers a potion that will embody these divisions' (Mighall 2002:xxii). Both the portrait of Dorian Gray and Mr Hyde are grotesque manifestations of secret opposite identities.

Stoker's Count Dracula participates in the trope of the double by being at different times both an old and a young man (apart from being able to shape-shift into an animal [Stoker 1993:105]). He is initially described as 'a tall old man, clean shaven save for a white moustache, and clad in black from head to foot' (Stoker 1993:25). However, before setting off for Britain, he is restored to a younger self: 'There lay the Count, but looking as if his youth had been half-renewed, for the white hair and moustache had changed to a dark iron-grey' (Stoker 1993:71).

Reading Gothic novels such as these helps give a better sense of the ethos of Wilde's novel, and, linked to this, a sharpened sense of cultural expression, its relation to its times and its way of coping with those times. 


\section{Cohen's monster theory}

Each of the Gothic texts mentioned above presents some aspects of humanity as monstrous. J.J. Cohen has proposed 'seven theses of monster theory'. He suggests, for instance, that monsters tend to be disfigured humans - this is the case with Doctor Frankenstein's monster, Dracula and zombies (Cohen 1996:12). It is also the case with Dorian Gray. Despite his human appearance, he does not age as other people do, is therefore unnatural, and so might be seen, according to Cohen's thesis, as a monster. Cohen (1996) states:

The monster of prohibition exists to demarcate the bonds that hold together the system of relations we call culture, to call horrid attention to the borders that cannot - must not be crossed. (p. 13)

What is important about Cohen's perception is that it enables us to see Dorian Gray not just as an aberrant being but also as a 'monster of prohibition', a challenge to our sense of what is permissible in life. He is a warning not to engage in the transgressive activities that threaten 'the system of relations we call culture'. While the historical perspective discussed at the end of the previous section has its own value, seeing the Gothic in general in the terms presented by Cohen might enable us to read The Picture of Dorian Gray in the light of a morality tale not limited to a particular time and place.

\section{Classical allusions}

Wilde's novel and those of Stevenson and Stoker are often seen as being part of the Gothic Revival that influenced architecture (especially), literature and art in Britain in the second half of the 19th century. During this same period, there was a renewed interest in the classical world of Greece and Rome. According to Franny Moyle, there had been 'growing interest in classical subjects in the 1870s and 1880s. Aestheticism in its quest for beauty found much to admire in classical precedents' (Moyle 2011:112). A possible reason is that archaeological discoveries in the Mediterranean, such as those of Schliemann at Troy and Mycenae, were making headlines in the late 19th century. These discoveries were reported in Britain and Europe in a popularly accessible manner, which spurred great interest (ed. Silverberg 1985:15). Apart from this fact, classical civilisation had been the prime focus of the great universities of Britain and Europe for centuries. It is hardly surprising that Wilde, youthful doyen of classical aestheticism, should employ classical allusions in his novel; his allusions, though, are of particular interest. Among the most notable are the references to Narcissus, the figure of male beauty, who, like Dorian Gray, is infatuated with his own image and dies tragically because of this. Because she is referred to as a 'white Narcissus' (Wilde 2003:74), the actress Sibyl Vane, with whom Dorian is initially in love (but then abandons), is linked in a slantwise way to the tragic abandonment of the infatuated girl in the Narcissus myth - the pleading Echo, a troubling repetitive vibration in the margins of perception as far as the self-obsessed Narcissus is concerned (Hughes 1997:249-50).

Sibyl Vane (and her name alludes to the 'Sibyl' of Roman vatic tradition) is described as beautiful, with 'a small Greek head' (Wilde 2003:50), an evocation of classical aesthetic ideals. Nassaar (1985) points out that this reference resonates with one by Pater in The Renaissance, in which he considers the head of the Mona Lisa:

Set it for a moment beside one of those white Greek goddesses or beautiful women of antiquity, and how would they be troubled by this beauty, into which the soul with all its maladies had passed. (p. 113)

That is, the classical world presented women's beauty as pure, while modernity expected art to address a more comprehensive representation of the world, including the need 'to deal with the grotesque' (Nassaar 1985:113); this is an observation with its own specific interest in the light of Wilde's novel, considering its link with the 'troubling' 'maladies' which 'pass' into Dorian's portrait.

Hermes is another classical figure who looms large in the novel and is important in certain specific respects. Firstly, in Chapter 2, Dorian, in discussion with Basil Hallward, states: 'I am less to you than your ivory Hermes or your silver Faun. You will like them always' (Wilde 2003:28). This speech takes place at a time in which Basil, Henry and Dorian are engaged in a discussion about ageing; his concern about the inevitability of his own ageing will lead Dorian to wish to remain forever young. Embedded in his remark to Basil is his desire to be like the Hermes artwork and retain the aesthetically informed admiration of Basil and Lord Henry.

Secondly, although Hermes is generally acknowledged to be the messenger (or herald) of the Greek gods, it is less well known that he is, according to M.C. Howatson, a psychopompos or 'guide of souls', which means that he is able to move between the world of the dead (the underworld) and the world of the living (Howatson 1997:273). As mentioned in the section on the 'double' and dualities, the idea of existing in two worlds is significant in terms of the novel: Dorian Gray, socialite and criminal, though hardly a 'guide' in any sense, moves between the world of the morally sound and the morally decadent (or, to frame the matter in extreme terms more closely aligned to the mythical context, between the world of the morally living and morally dead).

Thirdly, Hermes is the god of trickery, and according to Robert Graves, he was a thief and a liar before changing his nature; he stole Apollo's cattle while still an infant and lied about the theft (Graves 1955:63-64). Trickery and duplicity are clearly apparent in Dorian's nature, certainly making the oblique reference to Hermes apt in this case.

Fourthly, Hermes is the father of Hermaphroditus, a figure of great beauty, as noted by Stephen Fry in his recent work on Greek mythology, Mythos (2017). A water nymph, Salmacis, 
falls in love with him and calls on the gods to ensure that they are together forever. As a consequence, the gods fuse the male and female into one, making Hermaphroditus transgendered (Fry 2017:155). The story obviously has personal resonances for Wilde, but the obsession with immortal perfection also pertains to Dorian Gray.

Fifthly, Hermes is, too, the father of the satyr Silenus or Marsyas (as he is also known). According to Peter Ackroyd, Marsyas was Wilde's favourite classical Greek character (Ackroyd 1985:251). However, to ask 'why?' is perhaps to encourage idle psychological speculation, the reason might (again) have to do with the thematics of the novel (in part autobiographical), as considered in what follows. When Lord Henry states, 'I want music to-night. It seems to me that you are the young Apollo and that I am Marsyas listening to you' (Wilde 2003:206), he refers to Marsyas' doomed music competition with Apollo, which he lost - to be flayed alive as a consequence. Some readers might interpret this as a gruesome enough warning not to try to elevate the human beyond its proper bounds (a moral attached by some to the original myth). The moral applies equally to Dorian and Lord Henry, the one for his hubris and the other for encouraging it. Nassaar (1985:131) felt that 'Lord Henry has placed his soul entirely in his art - in Dorian - and when Dorian dies he loses it'.

That Lord Henry has in some way lost his aesthetically centred 'soul' is arguable - he considers all art as 'sterile', after all, implying a type of absence of soul in the first place (Wilde 2003:279) - but the idea brings us to the motif of the Faustian bargain, a key element of the novel.

\section{The Faustian bargain}

The mythos of the Faustian bargain (as found, for instance, in Christopher Marlowe and Goethe) is presented by Inez Hedges (2006) as follows:

With Faust, we mean someone who consciously, and usually irrevocably, betrays his (and later, her) sense of what is right in order to gain some desired advantage, and who thereby loses what is most precious and valuable about human life. The 'Faustian bargain' necessarily involves two characters: the tempted, to be sure, but also the tempter. (p. 1)

Milena Kostic makes the point that in the play by Marlowe, it is the victim himself, Faustus, who initiates the bargain - trading his soul for 24 years of the Devil's favours (Kostic 2013:20). In Wilde's novel too, it is the eventual victim, Dorian, who initiates a type of bargain (considering the presence of an implicit two-party tradeoff: material youth for spiritual decay), when he discusses the issue of ageing with Basil and Lord Henry and responds to the fact that the painting will not age: 'Oh, if it were only the other way! If the picture could change, and I could be always what I am now! ... I would give my soul for that!' (Wilde 2003:28). That Dorian's wish is granted implies a bargain struck, although with an invisible party or force, perhaps buried deep within Dorian himself (hinting once more at the psychological need for a double, free of the fear of death and human responsibility - a need that is the shadowy 'tempter', in this case, where even the 'soul' is at stake).

\section{Theatre and masks}

Also apparent in the novel are various references to theatrical drama. Theatre involves personae and masks, conceptual portraits, as it were, concealing the actual self. When initially discussing his relationship with Sibyl with Lord Henry, an infatuated Dorian tells of the various roles she plays, including Rosalind, Imogen and Juliet. When Lord Henry asks, 'When is she Sibyl Vane?', Dorian replies, 'Never' (Wilde 2003:54). This exchange reinforces the novel's theme of the desirability of an assumed identity and, by extension, the shortcomings of actual life. When Dorian does become aware of the actual woman, he is soon disenchanted and abandons her (Wilde 2003:103). W.B. Yeats (1955) records a pertinent remark by Wilde, in which the fellow Anglo-Irishman reveals his penchant for 'masks':

Olive Schreiner is staying in the East End because that is the only place where people do not wear masks upon their faces, but I have told her that I live in the West End because nothing interests me but the mask. (p. 165)

The sexually unconventional Wilde had reason to cultivate masks in his unenlightened era, but the statement could be interpreted more broadly: Wilde might be voicing a general perception that all people need to keep some aspect of themselves out of view, although the reasons for doing so might be of an ambivalent nature (as might their consequences). Dorian's perpetual youth masks him from the reality embodied in his portrait and the world around him, but is ultimately disfiguring and lethal.

\section{The influence of $A$ Rebours}

A significant detail to consider in the tragic arc of Dorian Gray's life is the influence of the yellow-backed French novel lent to him by Lord Henry. In his introduction to Against Nature (A Rebours) by Joris-Karl Huysmans (1884), Robert Baldick makes it clear that Wilde was here referring to Huysmans's novel. Wilde acknowledged this in one of his trials (Baldick 1959:5). In this novel we find a thematically important grotesquery: Huysmans (1959) describes the lithograph known as 'The Comedy of Death' by Rodolphe Bresdin - if not explicitly Gothic, it certainly participates in a Gothic atmosphere:

This depicts an improbable landscape which bristles with trees, coppices, and thickets in the shape of demons or phantoms and full of birds with rats' heads and vegetable tails. From the ground, which is littered with vertebrae, ribs, and skulls, there spring gnarled and shaky willow-trees, in which skeletons are perched, waving bouquets and chanting songs of victory. (p. 72) 
The reanimated skeletons 'chanting songs of victory' are at once a distorted form of resurrection and the denial of mortality, and a grisly reminder of inevitable human death. They are very much in the shadow, beyond the light of Ackroyd's 'fireside cosiness' referred to earlier in this article. In his introduction to A Rebours, Baldick makes the point that, according to many critics, the main character, Des Esseintes, is 'basically a self portrait' (Baldick 1959:11). However, Baldick felt that the character is also modern man, acutely aware that his pleasures are finite (Baldick 1959:13). This consciousness implies, in the fashion of Dorian Gray despairingly envying art's immortality, a recognition of his own inevitable end (as foreshadowed in the lithograph). Wilde, playing with the masks he himself has created in a somewhat autobiographical fashion, also rather chillingly foresees his own end. In an 1894 letter to Ralph Payne concerning The Picture of Dorian Gray, he writes: 'Basil Hallward is what I think I am: Lord Henry is what the world thinks me: Dorian what I would like to be' (in Holland 2006:170). Wilde therefore sees himself as an artist, but is aware of alternative versions of himself, and this connects with the novel's theme of doubled identity. There is also a tragic irony: Wilde, like Dorian and through Dorian, wishes for what he cannot be - eternally young. In the end, he does become like Dorian in a sense: a tragic figure in love with youth and caught in the toils generated by his own (for that era) self-destructive lifestyle.

\section{Conclusion}

An awareness of the various types of aesthetic and cultural input that go into the make-up of The Picture of Dorian Gray helps one fully to appreciate its significance as a cultural statement of continuing value. Its Gothic roots, Freud and the double, Faustian bargains, the monstrous, the mask, Huysmans' comedy of death - all offer the means of encouraging speculative and critical thinking about human beliefs, fears, actions and morality. The classical allusions provide access to tropes that have been prevalent in European culture for millennia, a fact educative in itself and serviceable in an appreciation of an historically wide range of literature, at least from Shakespeare to the present. These tropes helped inform 19th century aestheticism, linked to Symbolism, which in turn supplied one of the foundations of Modernism, itself at the basis of much contemporary cultural expression. How cunning of Wilde to begin a novel which is such a rich source of cultural largess with that provocatively ambiguous dictum, 'All art is quite useless'.

\section{Acknowledgements Competing interests}

The author declares that he has no financial or personal relationships that may have inappropriately influenced him in the writing of this research article.

\section{Author's contribution}

D.E.R. is the sole author of this article.

\section{Ethical considerations}

This article followed all ethical standards for research without direct contact with human or animal subjects.

\section{Funding information}

This research received no specific grant from any funding agency in the public, commercial or not-for-profit sectors.

\section{Data availability}

Data sharing is not applicable to this article as no new data were created or analysed in this study.

\section{Disclaimer}

The views and opinions expressed in this article are those of the author and do not necessarily reflect the official policy or position of any affiliated agency of the author.

\section{References}

Abrams, M.H. \& Harpham, G., 2012, A glossary of literary terms, 10th edn., Cengage, London.

Ackroyd, P., 1985, Introduction and notes to the Picture of Dorian Gray, Penguin Books, London.

Baldick, R., 1959, Introduction and notes to Huysmans, J-K. against nature [A rebours], Penguin Books, London.

Botting, F., 2005, Gothic, Routledge, New York, NY.

Cavallaro, D., 2002, The gothic vision, Continuum, London.

Cohen, J.J., 1996, Monster theory: Reading culture, University of Minnesota Press, Minneapolis, MN.

Department of Basic Education (DBE), 2016, Circular E 39, Department of Basic Education, Pretoria.

Department of Basic Education (DBE), 2018, Grade 12 English home language examination paper 2, Department of Basic Education, Pretoria.

Ellmann, R., 1987, Oscar Wilde, Hamish Hamilton, London.

Fitzsimons, E., 2015, Wilde's women, Duckworth, London.

Freud, S., 2003, The uncanny, Penguin Books, London.

Fry, S., 2017, Mythos, Penguin Books, London.

Gardiner, J., 1995, Oscar Wilde: A life in letters, writings, and wit, Collins and Brown, London.

Graves, R., 1955, The Greek myths volume one, Penguin Books, London.

Hedges, I., 2006, Framing Faust: Twentieth-century cultural struggles, Southern Illinois University Press, Carbondale, IL.

Holland, M., 2006, Oscar Wilde: A life in letters, Harper Collins, London.

Howatson, M.C., 1997, The Oxford companion to classical literature, Oxford University Press, Oxford.

Hughes, T., 1997, Tales from Ovid, Faber and Faber, London.

Huysmans, J.-K., 1959, Against nature [A Rebours], transl. R. Baldick, Penguin Books, London.

Kostic, M., 2013, The Faustian Motif in the tragedies of Christopher Marlowe, Cambridge Scholars Publisher, Cambridge.

Maturin, C., 1977, Melmoth the wanderer, Penguin Books, London.

Mighall, R., 2000, Introduction and notes to the Picture of Dorian Gray, Penguin Books, London.

Mighall, R., 2002, Introduction and notes to the strange case of Dr Jekyll and Mr Hyde, Penguin Books, London.

Moyle, F., 2011, Constance: The tragic and scandalous life of Mrs Oscar Wilde, John Murray, London.

Mulvey-Roberts, M. (ed.), 1998, The handbook to gothic literature, Macmillan, London.

Nassaar, C.S., 1985, 'The darkening lens', in H. Bloom (ed.), Modern critical views: Oscar Wilde, pp. 107-132, Chelsea House Publishers, New York, NY.

Pater, W. \& Wilde, O., 2003, 'Art for art's sake', Arts Education Policy Review 104(5), 29-31. https://doi.org/10.1080/10632910309600060 
Ryder, S., 2013 'Son and parents: Speranza and Sir William Wilde', in K. Powell. \& P. Raby (eds.), Oscar Wilde in context, pp. 7-16, Cambridge University Press, Cambridge.

Silverberg, R. (ed.), 1985, Great adventures in archaeology, Penguin Books, London.

Smith, A., 2013, Gothic literature, Edinburgh University Press, Edinburgh.

Stevenson, R.L., 2002, The strange case of Dr Jekyll and Mr Hyde, Penguin Books, London.

Stoker, B., 1993, Dracula, Penguin Books, London.
Sturgis, M., 2018, Oscar: A life, Head of Zeus, London.

Wagner, T., 2014, 'Gothic and the Victorian home', in G. Byron \& D. Townshend (eds.), The gothic world, Routledge, London.

Wilde, O., 2003, The Picture of Dorian Gray, Penguin Books, London.

Wilde, O., 2015, De Profundis, in Oscar Wilde: The Dover reader, Dover Thrift Editions, New York, NY.

Wright, T., 2008, Oscar's books, Chatto and Windus, London.

Yeats, W.B., 1955, Autobiographies, Macmillan, London. 